\title{
Intra-arterial milrinone may differentiate fulminant RCVS from vasculitis
}

Figure 1 CT angiogram, brain CT, and diffusion-weighted imaging (DWI) on MRI consistent with both reversible cerebral vasoconstriction syndrome and vasculitis

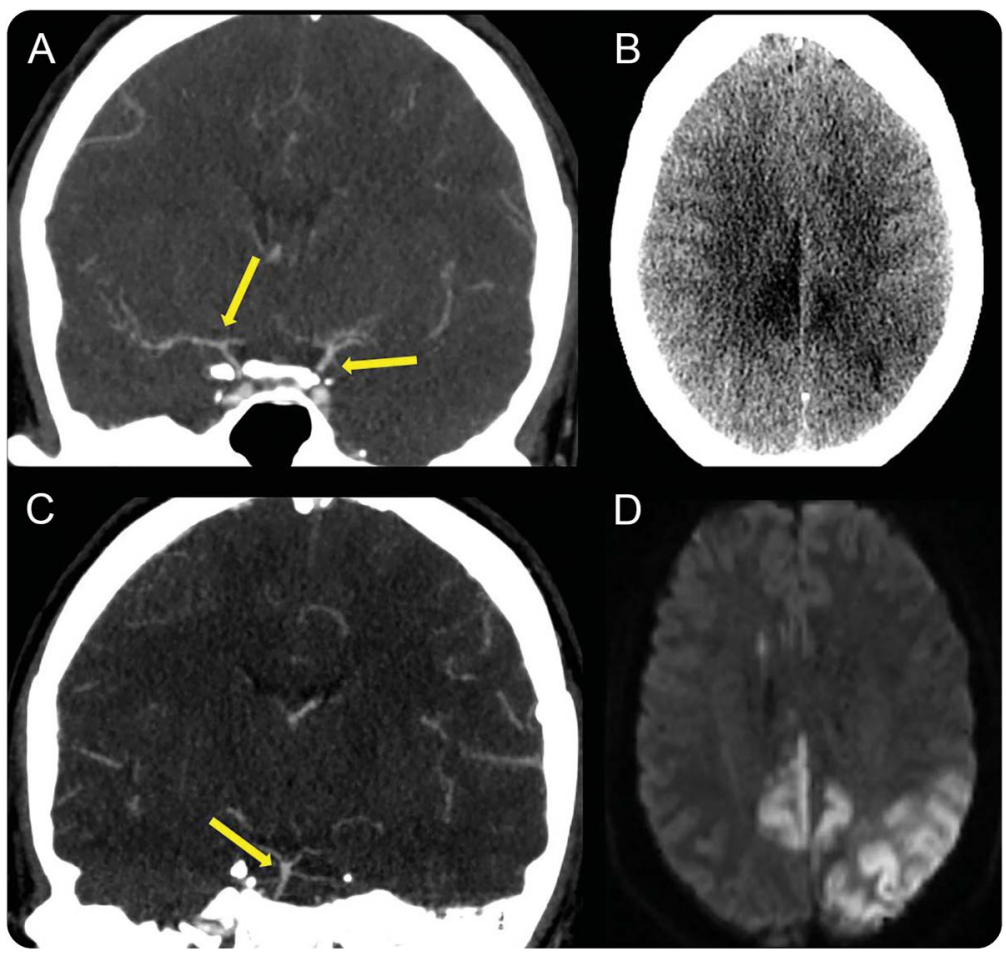

Substantial narrowing of vessels in the anterior circulation bilaterally (A) and the basilar artery (C). Bilateral medial parietal and left lateral parietal infarcts on noncontrast CT (B) and DWI (D).

A 39-year-old woman taking a monoamine oxidase inhibitor presented with a 1-week history of severe non-thunderclap headache and visual field deficits. Brain CT showed infarcts in both parietal lobes, with narrowing of intracranial vessels on CT angiogram (figure 1), suggesting either vasculitis or reversible cerebral vasoconstriction syndrome (RCVS). Despite treatment with both methylprednisolone and nimodipine, she experienced progressive aphasia and right leg weakness. She underwent an urgent cerebral angiogram (figure 2), during which intra-arterial milrinone reversed both the vasoconstriction and its symptoms, thereby confirming RCVS. Intra-arterial milrinone may be useful to differentiate vasculitis from RCVS ${ }^{1}$ and may serve as a treatment for RCVS, but requires prospective evaluation.

Michelle Laneuville, MD, Joy Ding, MD, Michel Shamy, MD, MA, FRCPC, Cheemun Lum, MD, FRCPC, Dar Dowlatshahi, $M D, P h D, F R C P C$

From The Ottawa Hospital, Canada.

Acknowledgment: The authors acknowledge coauthor Dr. Cheemun Lum, who died prior to publication of this article.

Author contributions: Michelle Laneuville: clinical care of patient, drafting and revising the manuscript. Joy Ding: clinical care of patient, drafting and revising the manuscript. Michel Shamy: clinical care of patient, drafting and revising the manuscript. Cheemun Lum: imaging acquisition and revising the manuscript. Dar Dowlatshahi: case concept and revising the manuscript.

Study funding: No targeted funding reported. 

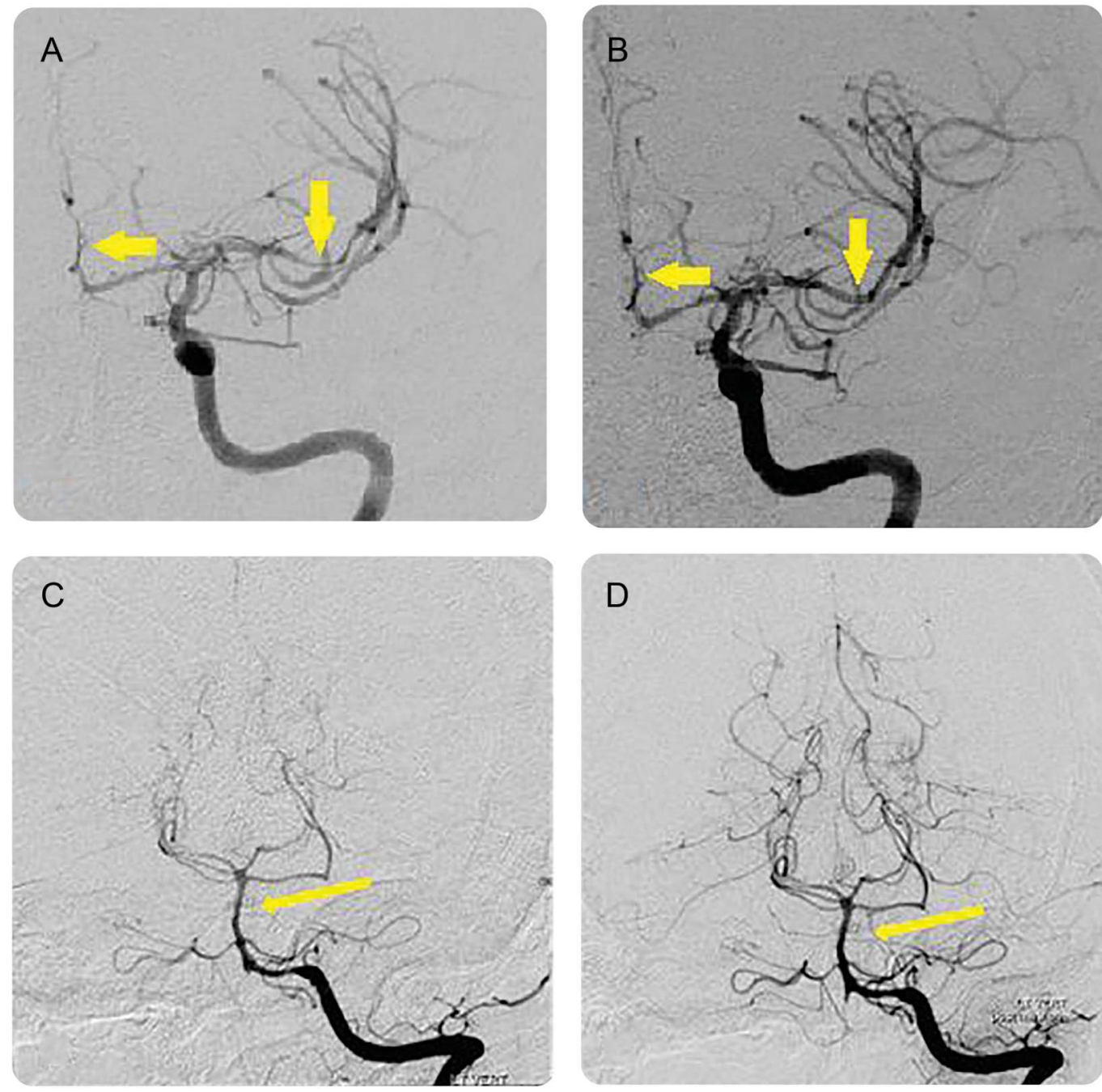

Left internal carotid artery angiogram before (A) and after (B) intra-arterial milrinone injection. Left vertebral artery angiogram before (C) and after (D) intra-arterial milrinone.

Disclosure: The authors report no disclosures relevant to the manuscript. Go to Neurology.org for full disclosures.

Correspondence to Dr. Laneuville: mlaneuville@toh.ca

1. Singhal AB, Topcuoglu MA. Glucocorticoid-associated worsening in reversible cerebral vasoconstriction syndrome. Neurology 2017;88:228-236. 


\section{Neurology}

\section{Intra-arterial milrinone may differentiate fulminant RCVS from vasculitis}

Michelle Laneuville, Joy Ding, Michel Shamy, et al.

Neurology 2017;89;1093-1094

DOI 10.1212/WNL.0000000000004337

This information is current as of September 4, 2017

\section{Updated Information \&} Services

\section{References}

Citations

Subspecialty Collections

Permissions \& Licensing

Reprints including high resolution figures, can be found at: http://n.neurology.org/content/89/10/1093.full

This article cites 1 articles, 1 of which you can access for free at: http://n.neurology.org/content/89/10/1093.full\#ref-list-1

This article has been cited by 5 HighWire-hosted articles: http://n.neurology.org/content/89/10/1093.full\#\#otherarticles

This article, along with others on similar topics, appears in the following collection(s):

\section{All Headache}

http://n.neurology.org/cgi/collection/all_headache

Other cerebrovascular disease/ Stroke

http://n.neurology.org/cgi/collection/other_cerebrovascular_disease_st roke

Information about reproducing this article in parts (figures,tables) or in its entirety can be found online at:

http://www.neurology.org/about/about_the_journal\#permissions

Information about ordering reprints can be found online:

http://n.neurology.org/subscribers/advertise

Neurology ${ }^{\circledR}$ is the official journal of the American Academy of Neurology. Published continuously since 1951, it is now a weekly with 48 issues per year. Copyright @ 2017 American Academy of Neurology. All rights reserved. Print ISSN: 0028-3878. Online ISSN: 1526-632X.

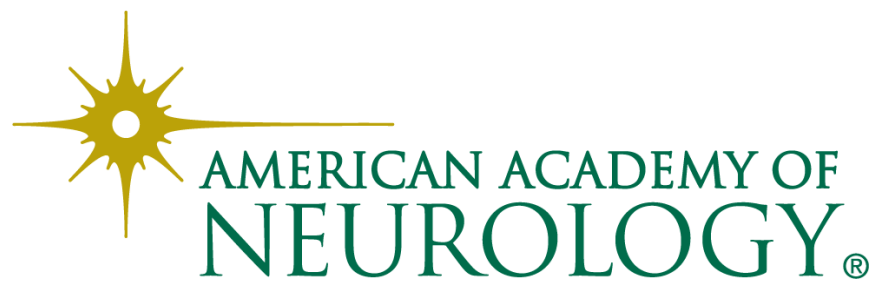

